\title{
Rapid mass growth and enhanced light extinction of atmospheric aerosols during the heating season haze episodes in Beijing revealed by aerosol-chemistry-radiation-boundary layer interaction
}

\author{
Zhuohui Lin ${ }^{1}$, Yonghong Wang ${ }^{2,3}$, Feixue Zheng ${ }^{1}$, Ying Zhou ${ }^{1}$, Yishuo Guo ${ }^{1}$, Zemin Feng ${ }^{1}$, Chang Li $^{1}$, \\ Yusheng Zhang ${ }^{1}$, Simo Hakala ${ }^{2}$, Tommy Chan ${ }^{2}$, Chao Yan ${ }^{2}$, Kaspar R. Daellenbach ${ }^{2}$, Biwu Chu ${ }^{3}$, Lubna Dada ${ }^{2}$, \\ Juha Kangasluoma ${ }^{1,2}$, Lei Yao ${ }^{2}$, Xiaolong Fan ${ }^{1}$, Wei Du ${ }^{2}$, Jing Cai ${ }^{2}$, Runlong Cai ${ }^{2}$, Tom V. Kokkonen ${ }^{2,4}$, \\ Putian Zhou $^{2}$, Lili Wang ${ }^{5}$, Tuukka Petäjä ${ }^{2,4}$, Federico Bianchi ${ }^{1,2}$, Veli-Matti Kerminen ${ }^{2,4}$, Yongchun Liu ${ }^{1}$, and \\ Markku Kulmala ${ }^{1,2,4}$ \\ ${ }^{1}$ Aerosol and Haze Laboratory, Beijing Advanced Innovation Center for Soft Matter Science and Engineering, \\ Beijing University of Chemical Technology, Beijing, China \\ ${ }^{2}$ Institute for Atmospheric and Earth System Research/Physics, Faculty of Science, University of Helsinki, Helsinki, Finland \\ ${ }^{3}$ Research Center for Eco-Environmental Sciences, Chinese Academy of Science, Beijing, China \\ ${ }^{4}$ Joint international research Laboratory of Atmospheric and Earth SysTem sciences (JirLATEST), \\ Nanjing University, Nanjing, China \\ ${ }^{5}$ State Key Laboratory of Atmospheric Boundary Layer Physics and Atmospheric Chemistry (LAPC), \\ Institute of Atmospheric Physics, Chinese Academy of Sciences, Beijing 100029, China
}

Correspondence: Yonghong Wang (yonghongwang@rcees.ac.cn)

Received: 7 March 2020 - Discussion started: 28 May 2020

Revised: 20 July 2021 - Accepted: 20 July 2021 - Published: 16 August 2021

\begin{abstract}
Despite the numerous studies investigating haze formation mechanism in China, it is still puzzling that intensive haze episodes could form within hours directly following relatively clean periods. Haze has been suggested to be initiated by the variation of meteorological parameters and then to be substantially enhanced by aerosol-radiationboundary layer feedback. However, knowledge on the detailed chemical processes and the driving factors for extensive aerosol mass accumulation during the feedback is still scarce. Here, the dependency of the aerosol number size distribution, mass concentration and chemical composition on the daytime mixing layer height (MLH) in urban Beijing is investigated. The size distribution and chemical composition-resolved dry aerosol light extinction is also explored. The results indicate that the aerosol mass concentration and fraction of nitrate increased dramatically when the MLH decreased from high to low conditions, corresponding to relatively clean and polluted conditions, respectively. Particles having their dry diameters in the size of $\sim 400$ $700 \mathrm{~nm}$, and especially particle-phase ammonium nitrate and
\end{abstract}

liquid water, contributed greatly to visibility degradation during the winter haze periods. The dependency of aerosol composition on the MLH revealed that ammonium nitrate and aerosol water content increased the most during low MLH conditions, which may have further triggered enhanced formation of sulfate and organic aerosol via heterogeneous reactions. As a result, more sulfate, nitrate and water-soluble organics were formed, leading to an enhanced water uptake ability and increased light extinction by the aerosols. The results of this study contribute towards a more detailed understanding of the aerosol-chemistry-radiation-boundary layer feedback that is likely to be responsible for explosive aerosol mass growth events in urban Beijing.

\section{Introduction}

Despite the recent reduction of air pollutants and their precursors in China between 2013 and 2017, the current emission and air pollution levels are still substantially high (Y. Wang 
et al., 2020b; Zheng et al., 2018). Such high emissions, combined with specific meteorological conditions, frequently lead to severe haze episodes (An et al., 2019; Wang et al., 2019). Particulate matter, a major air pollutant, has considerable effects on climate, human health and visibility degradation (Che et al., 2007; Lelieveld et al., 2015; Spracklen et al., 2008; Wang et al., 2015).

During winter haze episodes, a rapid growth of the aerosol mass concentration has commonly been observed, and this phenomenon seems to be directly affected by meteorological factors (J. Li et al., 2018; Liu et al., 2018; Z. Liu et al., 2019; H. Wang et al., 2018; J. Wang et al., 2014). The meteorological conditions and increased aerosol concentrations are proposed to be interlinked by a feedback loop, called the aerosol-chemistry-boundary layer feedback, in which aerosol particles reduce both solar radiation reaching the surface and turbulent kinetic energy (TKE) of the near-surface air (Ding et al., 2016; Petäjä et al., 2016; Wang et al., 2020d). The reduced TKE owing to aerosol reduces the entrainment of relatively dry air into the mixing layer from above, which makes the air more humid within the mixing layer. The increased relative humidity due to decreased surface temperature enhances the aerosol water uptake ability and promotes secondary aerosol formation via aqueous-phase reactions, enhancing light scattering and causing further reduction of solar radiation reaching the surface. All of these factors lead to increased stability of mixing layer height and enhanced air pollution in the mixed layer, which further suppresses the development of boundary layer. As a consequence, concentrations of primary aerosol particles, water vapour and relative humidity increase, creating more favourable conditions for homogeneous and heterogeneous reactions on aerosol surfaces or inside them (Cheng et al., 2016; Wang et al., 2016; Wu et al., 2018). Such reactions cause rapid formation of secondary aerosol matter and enhanced light extinction during severe winter haze episodes. However, more detailed information on the aerosol and reactive gas chemistry during the aerosol-chemistry-boundary layer feedback and related rapid aerosol mass growth events is still needed (Z. Liu et al., 2019). For instance, it is still unclear which chemical reactions and which compounds in the particulate matter play key roles during such rapid mass growth events.

The particle number size distribution and chemical composition are considered to be the most important variables influencing the light extinction by aerosol particles. In the atmosphere, the highest contribution to aerosol light extinction comes from organic compounds, nitrate and sulfate in particles with diameters of $100-1000 \mathrm{~nm}$. This is due to the dominant mass fractions of the aforementioned compounds in aerosols that correspond to the peak intensity of solar radiation at wavelengths around $550 \mathrm{~nm}$ (Jimenez et al., 2009; Swietlicki et al., 2008). In addition, light scattering, which contributes the most to the light extinction by atmospheric aerosols, can be substantially enhanced by the presence of liquid water in the aerosol (Chen et al., 2014; G. Liu et al.,
2019; Pan et al., 2009; Y. Wang et al., 2020a). Hence, quantifying the response of light extinction to different chemical compounds would be helpful in evaluating the feedbacks associated with secondary aerosol production.

In this study, we focus on the physical and chemical properties of aerosols in Beijing during the winter heating season from October 2018 to February 2019 using state-of-the-art instrumentation. The variation of aerosol chemical composition and the associated light extinction coefficient as a function of the varying mixing layer height are discussed. Our aim is to identify the key chemical components which contribute to the aerosol-chemistry-radiation-boundary layer feedback loop in Beijing.

\section{Methodology}

\subsection{Measurement location and instrumentations}

Measurements were conducted between 1 October 2018 and 28 February 2019 at the rooftop of the university building at the west campus of Beijing University of Chemical Technology $\left(39.95^{\circ} \mathrm{N}, 116.31^{\circ} \mathrm{E}\right)$. This station is located about $150 \mathrm{~m}$ away from the nearest road (Zizhuyuan Road) and $500 \mathrm{~m}$ away from the West Third Ring Road, and it is surrounded by commercial properties and residential dwellings representative of an urban environment. More details on the location can be found in Liu et al. (2020) and Zhou et al. (2020).

The meteorological data for this work include basic meteorological variables (relative humidity $(\mathrm{RH})$, temperature, wind speed, wind direction and visibility) and mixing layer height (MLH) measured using a weather station (Vaisala Inc., Finland) and a Ceilometer CL51 (Vaisala Inc., Finland), respectively. The MLH is defined as the height above the surface, through which relatively vigorous vertical mixing occurs (Holzworth, 1972), and its value is highly related to the vertical temperature structure and, to some extent, to a mechanically induced turbulence (Baxter, 1991). Here, we followed the method introduced earlier by Münkel et al. (2007) and Eresmaa et al. (2012) in determining the MLH.

The number size distributions of aerosol particles from 6 to $840 \mathrm{~nm}$ were measured by a differential mobility particle sizer (DMPS) (Aalto et al., 2001). The mass concentration of fine particulate matter $\left(\mathrm{PM}_{2.5}\right)$ was measured using a Tapered Element Oscillating Microbalance Dichotomous Ambient Particulate Monitor (TEOM 1405-DF, Thermo Fisher Scientific Inc, USA) with a total flow rate of $16.67 \mathrm{~L} \mathrm{~min}^{-1}$ (Y. Wang et al., 2014).

A time-of-flight aerosol chemical speciation monitor (ToF-ACSM, Aerodyne Research Inc.) was used to measure the concentrations of non-refractory (NR) components, including sulfate, nitrate, ammonium, chloride and organics of $\mathrm{PM}_{2.5}$ (Fröhlich et al., 2013). A $\mathrm{PM}_{2.5}$ cyclone was deployed on the rooftop with a flow rate of $3 \mathrm{~L} \mathrm{~min}^{-1}$. The correlation 
coefficient of $\mathrm{PM}_{2.5}$ measured by TEOM and ToF-ACSM is around 0.9, which indicates the consistence of the two datasets. Aerosol was dried though a Nafion dryer (MD-70024F-3, PERMA PURE) before entering the ToF-ACSM. The inlet flow was set at $1.4 \mathrm{~cm}^{3} \mathrm{~s}^{-1}$. The particle beam passed through the chamber and reached the heated porous tungsten surface $\left(T \approx 600^{\circ} \mathrm{C}\right)$. There, the non-refractory $\mathrm{PM}_{2.5}$ constituents were vaporised and then ionised by electrons ( $E_{\text {kin }}=70 \mathrm{eV}$, emitted by a tungsten filament). The ions were measured by a detector, and the data were analysed using Tofware version 2.5.13 within Igor Pro version 6.3.7.2 (WaveMetrics). The relative ionisation efficiencies (RIEs) for sulfate, nitrate, ammonium, chloride and organics applied were $0.86,1.05,4.0,1.5$ and 1.4, respectively. Besides RIE correction, the data also did $\mathrm{CO}_{2}^{+} / \mathrm{NO}_{3}$ artifact correction (Pieber et al., 2016) and collection efficiency (CE) correction. The detailed information has been introduced in Cai et al. (2020). Mass concentrations of ammonium nitrate, ammonium sulfate and ammonium chloride were determined according to the method introduced by Gysel et al. (2007). The aerosol liquid water content (AWC) was calculated by the thermodynamic equilibrium model ISORROPIA II using ToF-ACSM data (Fountoukis and Nenes, 2007).

Highly oxygenated organic molecules (HOMs) were measured by a chemical ionisation long time-of-flight mass spectrometer equipped with a nitrate chemical ionisation source (LToF-CIMS, Aerodyne Research, Inc., USA) (Jokinen et al., 2012) similar to gas-phase sulfuric acid. The ambient air was drawn into the ionisation source through a stainless-steel tube with a length of $\sim 1.6 \mathrm{~m}$ and a diameter of $3 / 4$ in. at a flow rate of $\sim 8 \mathrm{~L} \mathrm{~min}^{-1}$. A $30-40 \mathrm{Lmin}^{-1}$ purified air flow and a 4-8 $\mathrm{mL} \mathrm{min}^{-1}$ ultrahigh purity nitrogen flow containing nitric acid were mixed together as the sheath flow, which is guided through a PhotoIonizer (Model L9491, Hamamatsu, Japan) to produce nitrate reagent ions. This sheath flow is then introduced into a co-axial laminar flow reactor concentric to the sample flow. Nitrate ions are pushed to the sample flow layer by an electric field and subsequently charge analytical molecules. Organic carbon (OC) and element carbon (EC) concentrations were measured semi-continuously with a $1 \mathrm{~h}$ time resolution using an OC/EC analyser (Model-4, Sunset Laboratory Inc.) and time series of ACSM Org and Sunset OC as shown in Fig. S6.

The ammonia is measured by the Trace Ammonia Analyser (Los Gatos Research, Inc.) at atmospheric ambient levels with high precision $(0.2 \mathrm{ppb}$ in $1 \mathrm{~s})$ and ultra-fast response (5 Hz).

The air mass history was studied by calculating particle retroplumes using the Lagrangian particle dispersion model FLEXPART (FLEXible PARTicle dispersion model) version 9.02 (Stohl et al., 2005). The ECMWF (European Centre for Medium-Range Weather Forecasts) operational forecast (with $0.15^{\circ}$ horizontal and $1 \mathrm{~h}$ temporal resolution) was used as the meteorological input into the model. During the measurement period, a new release of 50000 test particles, dis-
Table 1. Summary of the parameters for calculating the average optical refractive index.

\begin{tabular}{lccc}
\hline Species & $\rho_{i}\left(\mathrm{~g} \mathrm{~cm}^{-3}\right)$ & $n_{i}$ & $k_{i}$ \\
\hline$\left(\mathrm{NH}_{4}\right)_{2} \mathrm{SO}_{4}$ & 1.760 & 1.530 & 0.000 \\
$\mathrm{NH}_{4} \mathrm{NO}_{3}$ & 1.725 & 1.554 & 0.000 \\
$\mathrm{NH}_{4} \mathrm{Cl}$ & 1.527 & 1.639 & 0.000 \\
Organics & 1.400 & 1.550 & 0.001 \\
EC & 1.500 & 1.800 & 0.540 \\
\hline
\end{tabular}

tributed evenly between 0 and $100 \mathrm{~m}$ above the measurement site, occurred every $1 \mathrm{~h}$. The released particles were traced backwards in time for $72 \mathrm{~h}$, unless they exceeded the model boundary $\left(20-60^{\circ} \mathrm{N}, 95-135^{\circ} \mathrm{E}\right)$.

\subsection{Aerosol light extinction calculation}

The aerosol light extinction coefficient was calculated with the Mie model, which uses particle number size distribution, mass concentrations of different aerosol compounds and their refractive index as inputs (Seinfeld and Pandis, 2006). We introduced a series of assumptions into the Mie model, including the following: (1) an "internal mixture" considers each chemical component in a particle as homogeneously mixed with each other; (2) all particles are spherical; and (3) particles of different sizes have the same chemical composition.

The practical method introduced under those assumptions in previous studies was found to be capable of estimating a variation trend of optical property of $\mathrm{PM}_{0.5-20}$ with a relatively good accuracy (Lin et al., 2013).

The average optical refractive index (AORI) of an internally mixed particle can be calculated from the optical refractive indices (ORIs) of each chemical component by following a mixing rule of volume-averaged chemical components as AORI $=n_{\text {eff }}+k_{\text {eff }} \times i$, where the real part $\left(n_{\mathrm{eff}}\right)$ and imaginary part $\left(k_{\text {eff }}\right)$ are given by

$$
\begin{aligned}
& n_{\mathrm{eff}}=\left(\sum_{i} n_{i} \cdot m_{i} / \rho_{i}\right) /\left(\sum_{i} m_{i} / \rho_{i}\right) \\
& k_{\mathrm{eff}}=\left(\sum_{i} k_{i} \cdot m_{i} / \rho_{i}\right) /\left(\sum_{i} m_{i} \cdot / \rho_{i}\right) .
\end{aligned}
$$

Here $m_{i}$ and $\rho_{i}$ are the mass concentration and density of the component $i$ in particles, respectively, and $n_{i}$ and $k_{i}$ are the real and imaginary parts of ORI of this component, respectively. The parameters for calculating the AORI are summarised in Table 1 . The values of $n_{i}$ and $k_{i}$ in Table 1 are referenced to the light wavelength of $550 \mathrm{~nm}$.

$Q_{\mathrm{sp}, j}$ represents light scattering efficiency of a single particle with diameter $D_{j}$, while $Q_{\mathrm{ep}, j}$ represents light absorption efficiency. Theoretically, $Q_{\mathrm{sp}, j}$ and $Q_{\mathrm{ep}, j}$ are both the function of $D_{j}$ and the $\mathrm{AORI}_{j}$ (the AORI of the particle with 
diameter $D_{j}$ ) at a given light wavelength $\lambda$, for which the complicated calculations were referenced to a previous publication (Lin et al., 2013). Regarding the limitations of measurement techniques, the $\mathrm{AORI}_{j}$ was assumed to be equal to the $\mathrm{AORI}_{\mathrm{PM}_{2.5}}$, which was determined based on chemical composition of $\mathrm{PM}_{2.5}$. It is possible to derive expressions for the cross sections of a spherical particle exactly. The formulas for $Q_{\mathrm{sp}, j}$ and $Q_{\mathrm{ep}, j}$ are as follows:

$$
\begin{aligned}
& Q_{\mathrm{sp}, j}\left(D_{j}, \lambda, \mathrm{AORI}_{j}\right)=\frac{2}{\alpha^{2}} \sum_{k=1}^{\infty}(2 k+1) \cdot\left[\left|a_{k}\right|^{2}+\left|b_{k}\right|^{2}\right] \\
& Q_{\mathrm{ep}, j}\left(D_{j}, \lambda, \mathrm{AORI}_{j}\right)=\frac{2}{\alpha^{2}} \sum_{k=1}^{\infty}(2 k+1) \cdot \operatorname{Re}\left[a_{k}+b_{k}\right],
\end{aligned}
$$

where

$$
\begin{aligned}
& a_{k}=\frac{\alpha \psi_{k}^{\prime}(y) \psi_{k}(\alpha)-y \psi_{k}^{\prime}(\alpha) \psi_{k}(y)}{\alpha \psi_{k}^{\prime}(y) \xi_{k}(\alpha)-y \xi_{k}^{\prime}(\alpha) \psi_{k}(y)} \\
& b_{k}=\frac{y \psi_{k}^{\prime}(y) \psi_{k}(\alpha)-\alpha \psi_{k}^{\prime}(\alpha) \psi_{k}(y)}{y \psi_{k}^{\prime}(y) \xi_{k}(\alpha)-\alpha \xi_{k}^{\prime}(\alpha) \psi_{k}(y)},
\end{aligned}
$$

with $y=\alpha m$.

$m=n_{\mathrm{eff}}+i \cdot k_{\mathrm{eff}}$

$\alpha=\frac{\pi D_{j}}{\lambda}$,

with $\lambda=550 \mathrm{~nm}$, where complex number $m$ stands for $\mathrm{AORI}_{j}$, while $\alpha$ is the size of the particle, usually expressed as a dimensionless size parameter. The functions $\psi_{k}(z)$ and $\xi_{k}(z)$ are the Riccati-Bessel functions:

$\psi_{k}(z)=\left(\frac{\pi z}{2}\right)^{1 / 2} J_{k+1 / 2}(z)$

$\xi_{k}(z)=\left(\frac{\pi z}{2}\right)^{1 / 2}\left[J_{k+1 / 2}(z)+i(-1)^{k} J_{-k-1 / 2}(z)\right]$,

where $J_{k+1 / 2}$ and $J_{-k-1 / 2}$ are the Bessel functions of the first kind and their subscripts indicate the order of Bessel functions. The Mie theory can serve as the basis of a computational procedure to calculate the scattering and absorption of light by any sphere as a function of wavelength.

According to the Mie model, $b_{\mathrm{sp}}$ (light scattering coefficient) and $b_{\text {ep }}$ (light extinction coefficient) can be quantified with Eqs. (5) and (6), respectively. $b_{\text {ap }}$ (light absorption coefficient) is the difference between $b_{\mathrm{ep}}$ and $b_{\mathrm{sp}}$, which equals zero, when $k_{i}$ equals zero or is very small. Optical properties including $b_{\mathrm{ep}}, b_{\mathrm{sp}}$ and $b_{\mathrm{ap}}$ to be discussed later are all referenced to light wavelength of $550 \mathrm{~nm}$.

$b_{\mathrm{sp}}=\sum_{j} b_{\mathrm{sp}, j}=\sum_{j} \frac{\pi D_{j}^{2}}{4} \cdot Q_{\mathrm{sp}, j}\left(D_{j}, \lambda, \mathrm{AORI}_{j}\right) \cdot N_{j}$

$b_{\mathrm{ep}}=\sum_{j} b_{\mathrm{ep}, j}=\sum_{j} \frac{\pi D_{j}^{2}}{4} \cdot Q_{\mathrm{ep}, j}\left(D_{j}, \lambda, \mathrm{AORI}_{j}\right) \cdot N_{j}$

In Eqs. (7) and (8), $D_{j}$ stands for the median Stokes diameter in the $j$ th particle size range and $N_{j}$ is the number concentration of particles with diameter, $D_{j}$.

\section{Results and discussion}

\subsection{An overview of the measurement campaign}

The time series particle number size distribution from 6 to $840 \mathrm{~nm}$ and mass concentrations of nitrate, organics, sulfate, ammonium and chloride in NR_PM 2.5 (non-refractory $\mathrm{PM}_{2.5}$ ) and $\mathrm{PM}_{2.5}$, concentration of HOMs and $\mathrm{OC}$ are shown in Fig. 1a-c. The statistics of these compounds are summarised in Table S1 in the Supplement. In general, they showed similar variation patterns (Figs. S2 and S3). These concentrations showed higher values during haze events than during clean days and increased significantly during nighttime. As shown in Fig. 1b, the rapid mass growth during the heating season in Beijing is related to the rapid growth in nitrate concentration. At the same time, the haze events $\left(\mathrm{PM}_{2.5}\right.$ concentration $\geq 75 \mu \mathrm{g} \mathrm{m}^{-3}$ and lasting more than $1 \mathrm{~d}$ ) are accompanied by particle size growth (Fig. 1a). To further study which particle size possesses the highest light extinction efficiency during the haze events, and to what extent nitrates contribute to light extinction with the variation of MLH, a case of rapid aerosol mass growth event is selected for further study.

\subsection{Typical case of rapid aerosol mass growth episodes affected by aerosol-chemistry-boundary layer interactions}

An example of rapid aerosol mass growth in urban wintertime Beijing is illustrated in Fig. 2, where the haze accumulation was associated with a rapid $\mathrm{PM}_{2.5}$ mass concentration increase from $8.5 \mu \mathrm{g} \mathrm{m}^{-3}$ to more than $100 \mu \mathrm{g} \mathrm{m}{ }^{-3}$ in less than $7 \mathrm{~h}$. A haze episode started in the afternoon of 20 February 2019 under stagnant meteorological conditions with low wind speeds and elevated ambient relative humidity (Fig. S4). The polluted periods during this case occurred under southerly wind transport conditions, whereas clean air masses originated from the north-westerly regions (as shown in Figs. S5 and S6). These are typical features for a haze evolution process in Beijing (Y. Wang et al., 2020b). During the haze periods marked by the shaded areas in Fig. 2, an obvious increase of chemical mass concentration was observed by the ToF-ACSM, characterised by high concentrations of secondary aerosol components (nitrate, organics and sulfate) and typically a shallow boundary layer. The mass concentrations of organics, sulfate and nitrate increased dramatically with a decreasing MLH, accounting for $88.5 \%$ of NR-PM 2.5 during the rapid aerosol mass growth period. The aerosol mass growth was the fastest for nitrate. The mass concentrations of organic and elemental carbon followed that of NR$\mathrm{PM}_{2.5}$.

The MLH reached its maximum at around 14:00 UTC +8 in the afternoon of 20 February, after which the development of the mixing layer was suppressed and MLH decreased with the arrival of pollution (Fig. 2a). Previous studies have 


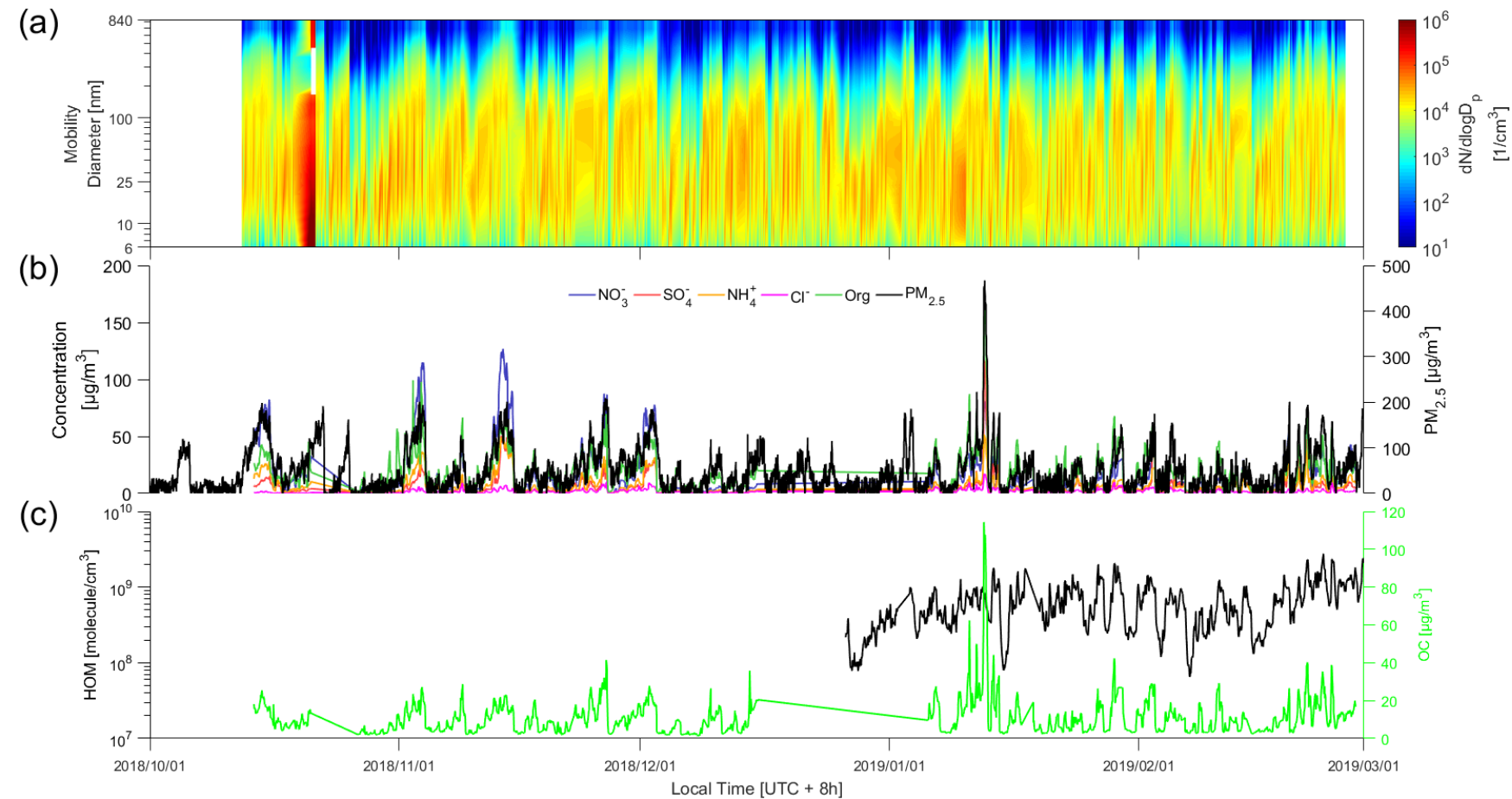

Figure 1. Time series of (a) particle number concentration distribution (PNSD) from 6 to $840 \mathrm{~nm}$ and (b) chemical composition of NR_PM 2.5 and $\mathrm{PM}_{2.5}$ mass concentrations. (c) The concentrations of organic carbon (OC) and highly oxygenated organic molecules (HOM).

(a)

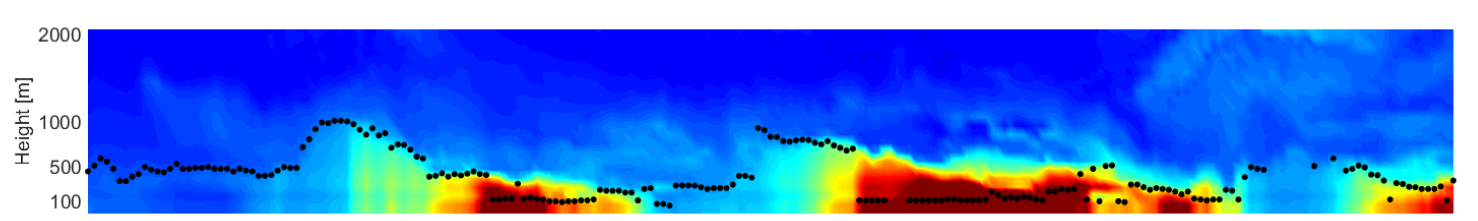

(b)

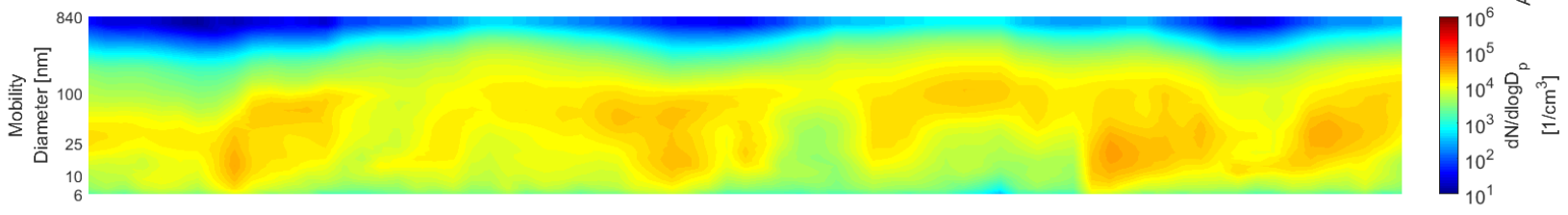

(c)

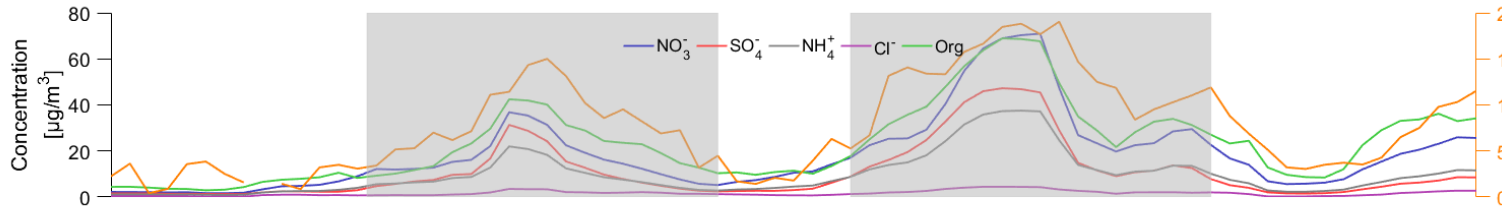

(d)

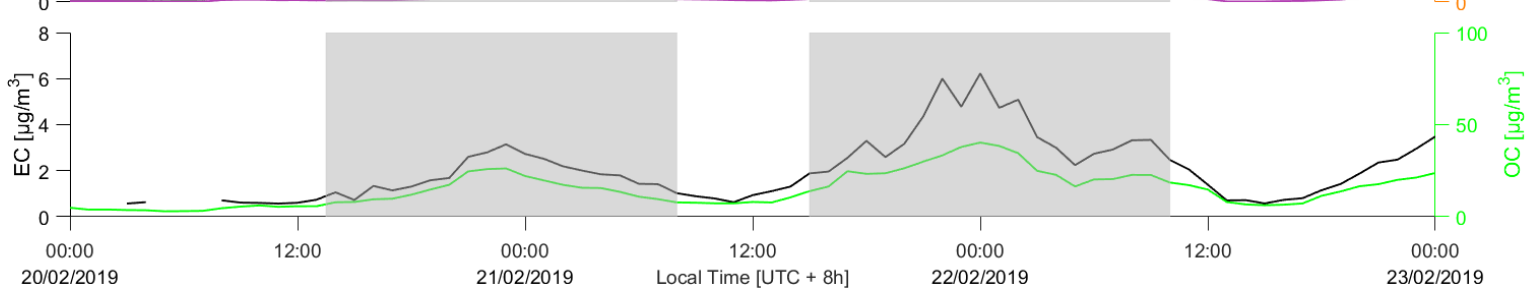

Figure 2. Time series of (a) attenuated backscattering coefficient and mixing layer height and (b) particle number concentration distribution (PNSD), (c) chemical composition and $\mathrm{PM}_{2.5}$ mass concentrations and (d) elemental carbon (EC) and organic carbon (OC). The haze periods are marked by the shaded areas. 
(a)

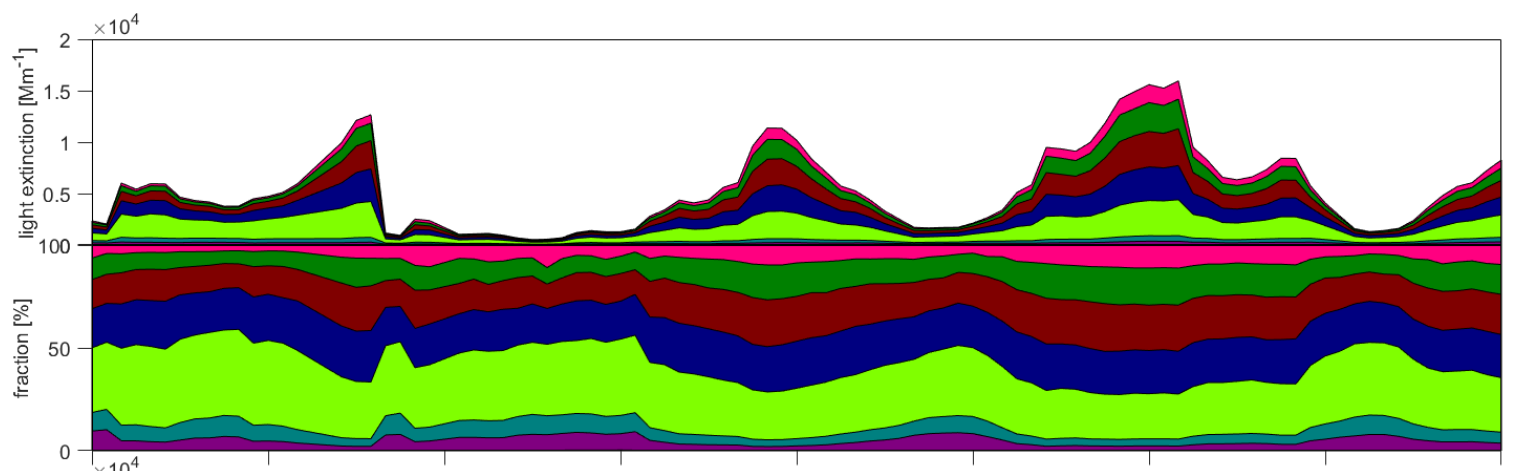

(c)

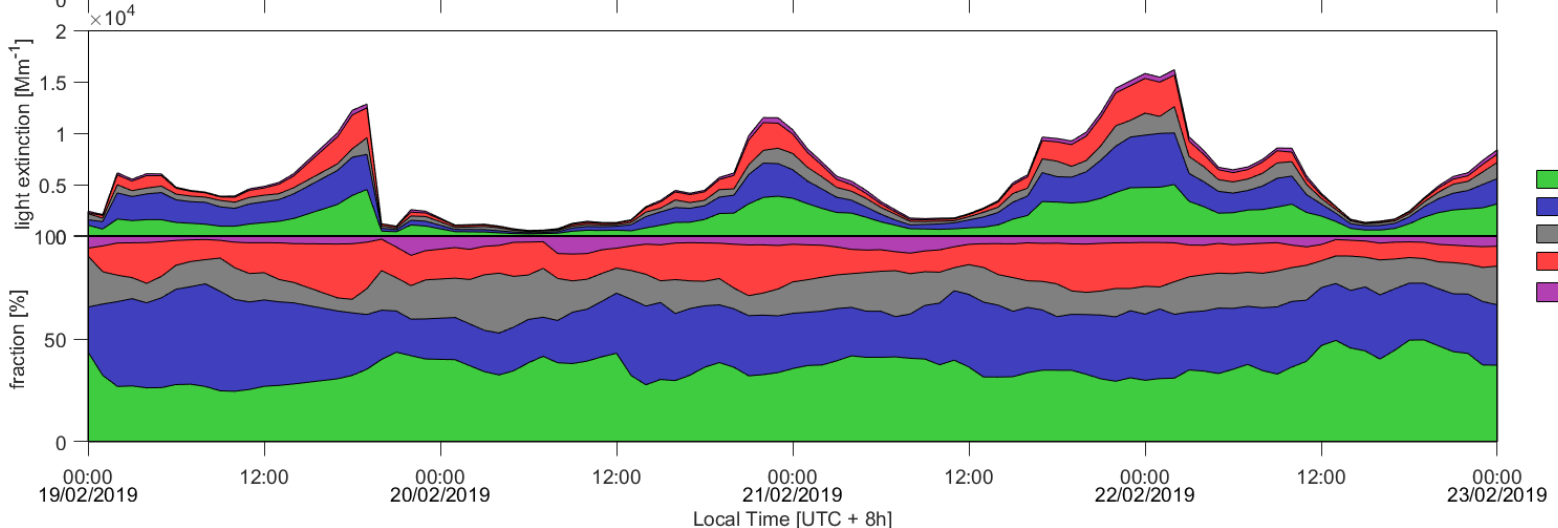

Figure 3. Time series of (a, b) variation of light extinction from different size aerosol and fractions and (c, d) variation of light extinction from different aerosol species and fractions. The legends on the left side of figures are particle diameter, and the right side are chemical compositions, respectively.

(a)

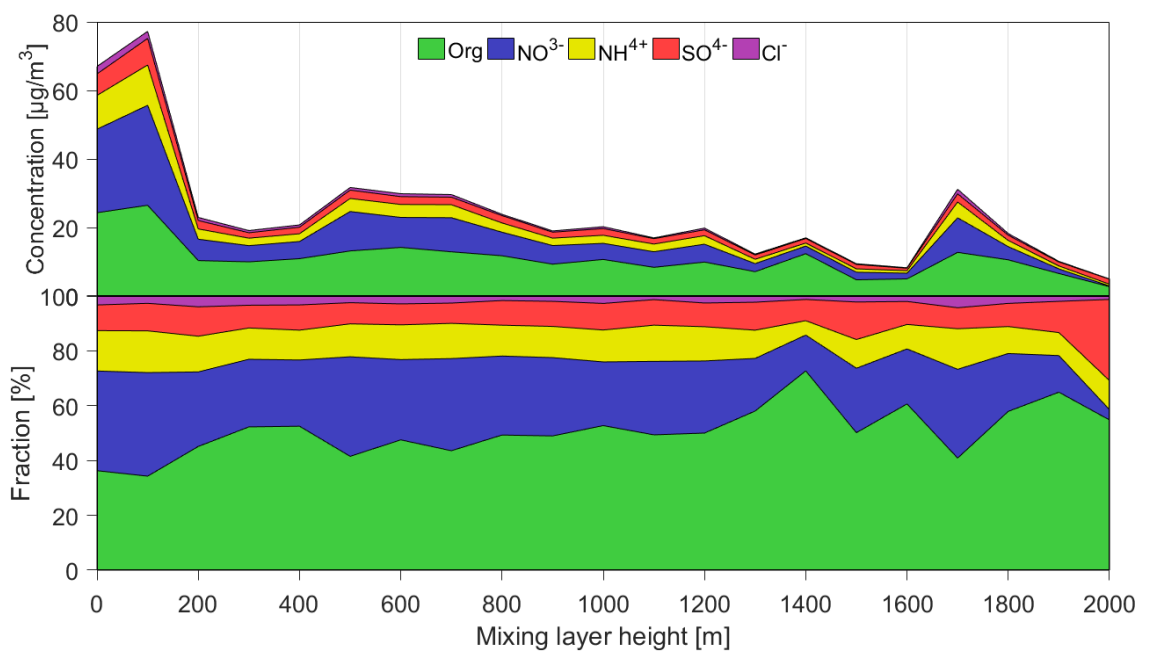

Figure 4. Statistical relationship between MLH and concentration (a) and fraction (b) of chemical composition species. Only daytime conditions determined by ceilometer from non-rainy periods $(\mathrm{RH}<95 \%)$ during the observation $(\sim 6$ months $)$ are considered.

shown that the aerosol-radiation-boundary layer feedback contributes to a rapid enhancement of air pollution (Petäjä et al., 2016; Y. Wang et al., 2020). High concentrations of aerosol particles obscure downward radiation, as a result of which the surface temperature and sensitive heat flux decrease and the development of mixing layer height is sup- pressed. Recent studies have gradually realised that the facilitation of various chemical processes plays a non-negligible role in the aerosol-radiation-boundary layer feedback (Liu et al., 2018; Z. Liu. et al., 2019). Therefore, it is important to identify and quantify the role of different specific chemi- 
(a)

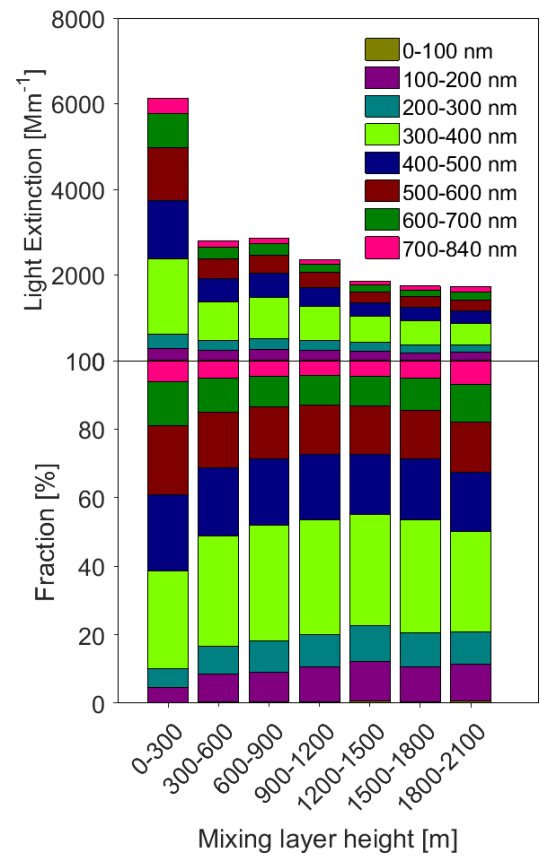

(c)

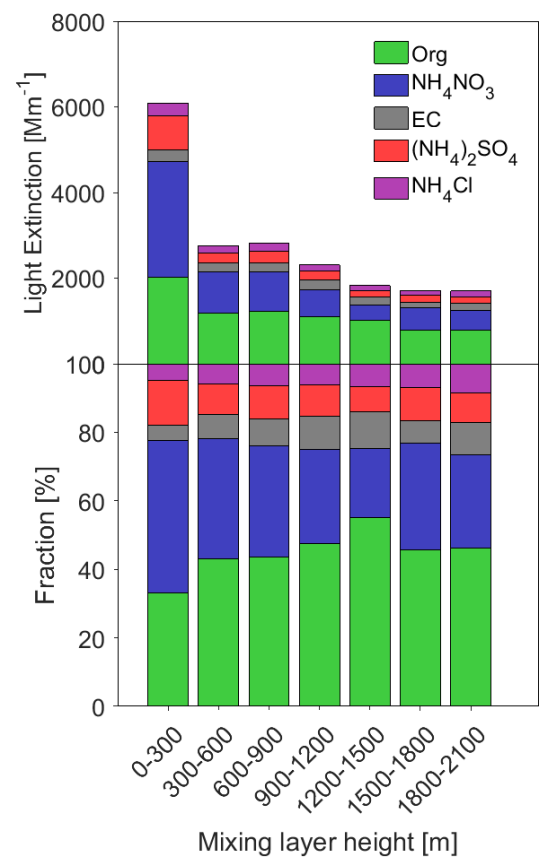

Figure 5. Statistical relationship between MLH and light extinction of different aerosol species. Only daytime conditions determined by the ceilometer from non-rainy periods $(\mathrm{RH}<95 \%)$ are considered.

cal species and particle size ranges in reducing atmospheric radiation and extinction.

Figure 3 shows the contributions of size and chemical composition-resolved dry aerosol to light extinction during the investigated period. As the pollution intensified and MLH decreased (Fig. 2c), the light extinction of atmospheric aerosols increased significantly. Assuming that par- ticles of different sizes have the same chemical composition as $\mathrm{PM}_{2.5}$ (organics, $\mathrm{NH}_{4} \mathrm{NO}_{3}, \mathrm{EC},\left(\mathrm{NH}_{4}\right)_{2} \mathrm{SO}_{4}, \mathrm{NH}_{4} \mathrm{Cl}$ ), the light extinction of particles in the size range of 300 $700 \mathrm{~nm}$ increased significantly from the relatively clean period to the polluted period (namely from 12:00 to 16:00). During relatively clean conditions, the contributions of organics, $\mathrm{NH}_{4} \mathrm{NO}_{3}, \mathrm{EC},\left(\mathrm{NH}_{4}\right)_{2} \mathrm{SO}_{4}$ and $\mathrm{NH}_{4} \mathrm{Cl}$ to the total aerosol light extinction were $42 \%, 23 \%, 18 \%, 11 \%$ and $7 \%$, respectively. The contribution of $\mathrm{NH}_{4} \mathrm{NO}_{3}$ to aerosol light extinction reached $40 \%$ during the heavily polluted period. Based on the observation it is likely that the increased light extinction by aerosols reduced solar radiation reaching the surface so that the development of the boundary layer was suppressed.

\subsection{Connection between the aerosol chemical composition, light extinction, size distribution and MLH during the heating season}

To better characterise the effect of the chemical composition of dry aerosols and the PNSD (particle number size distribution) light extinction under different MLH conditions, the daytime (8:00-16:00 LT) measurement data from October 2018 to February 2019 were selected for further analysis. As shown by Fig. 4 and consistent with other observations in Beijing (Tang et al., 2016; Y. Wang et al., 2020c), there was a general tendency for the $\mathrm{PM}_{2.5}$ mass concentration to increase with a decreasing MLH. Organic compounds and nitrate were the most abundant fractions of the daytime aerosol mass composition, contributing together approximately $70 \%$ to total NR-PM 2.5 mass concentration. With a decreasing $\mathrm{MLH}$, the fraction of nitrate mass in NR-PM 2.5 slightly increased while that of organics decreased. This feature makes the aerosol more hygroscopic under low MLH conditions typical for heavily polluted periods. The increased nitrate fraction in the aerosol could also enhance the formation of other secondary aerosol components (Xue et al., 2019). Note that some fraction of aerosol nitrate could consist of organic nitrate originating from reaction of peroxy radical with nitric oxide; however, it is difficult to distinguish organic nitrate from inorganic nitrate at the moment due to instrumental limitations (Fröhlich et al., 2013).

Figure 5 depicts the calculated daytime light extinction of the dry aerosol as a function of the MLH, separated by different size ranges and chemical components. We may see that in general, particles with dry diameters in the range of 300 $700 \mathrm{~nm}$ explain more than $80 \%$ of the total aerosol light extinction (Fig. 5b). Similar to their share in NR-PM 2.5 , the fraction of light extinction by ammonium nitrate increased and that of organics decreased during the lowest MLH conditions corresponding to the heavy pollution periods (Fig. 5d). There are also apparent differences in the relative contribution of different particle size ranges to light extinction in different MLH conditions: with a decreasing MLH, the contribution of particles with dry diameters larger than about 400 

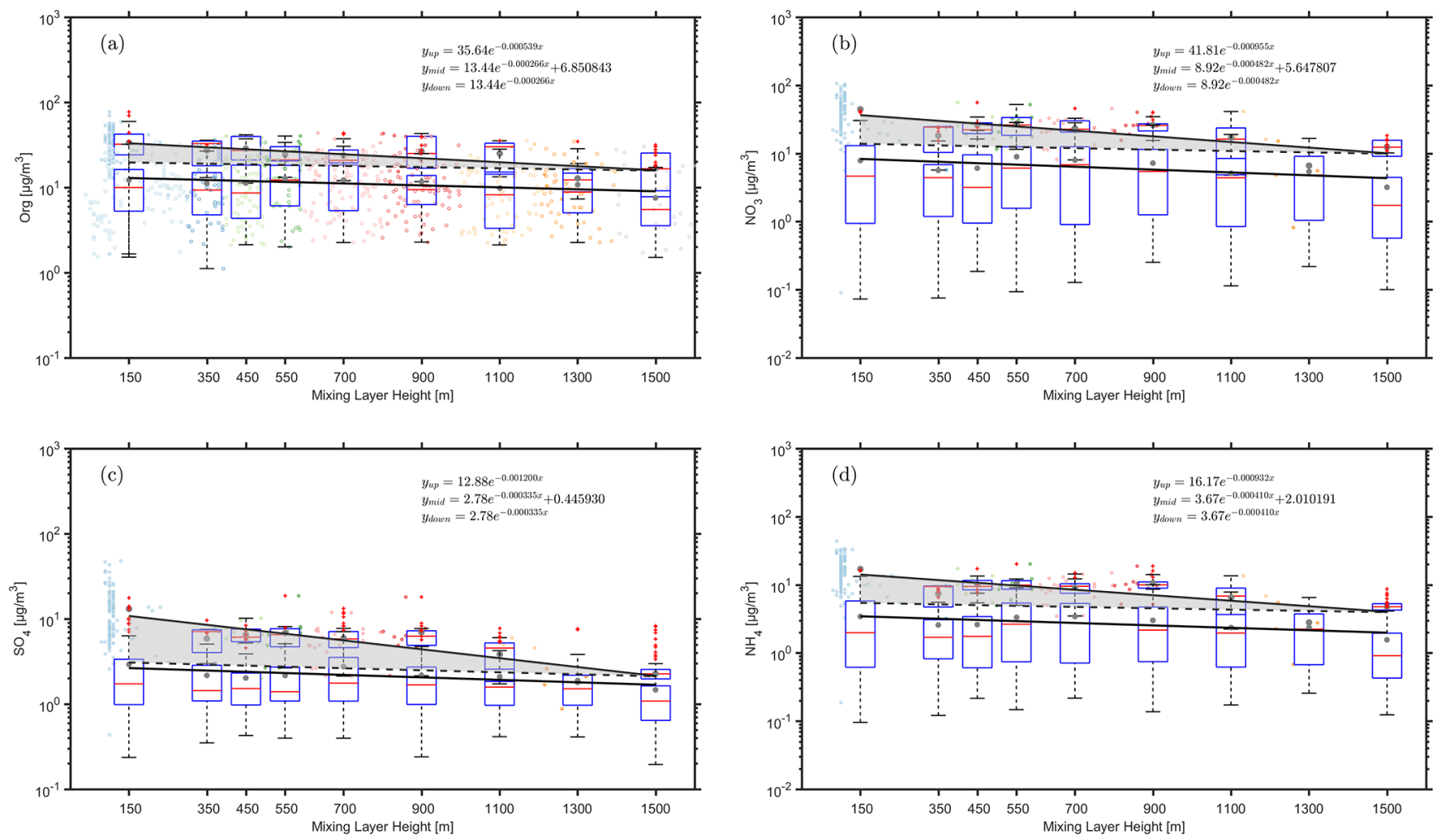

Figure 6.

$500 \mathrm{~nm}$ clearly increased while that of sub-300 nm particles notably decreased. This indicates that the enhanced light extinction by the dry aerosol at low MLH conditions was not only due the more abundant aerosol mass concentration, but also due to the growth of individual particles to optically more active sizes.

At relative humidity larger than about $70 \%$, aerosol liquid water gives a significant contribution to the aerosol mass concentration and often a dominant contribution to the aerosol light extinction (Titos et al., 2016). This has important implications for the aerosol-chemistry-radiation-boundary layer feedback, when considering our findings listed above and further noting that heavy pollution periods are often accompanied by high values of RH in Beijing (Zhong et al., 2018). First, compared to clean or moderately polluted conditions, the enhancement in the aerosol light extinction under polluted conditions is probably much larger than that illustrated in Fig. 5. Second, the high aerosol water content under polluted conditions promotes many kinds of chemical reactions taking place on the surface or inside aerosol particles.

\subsection{Aerosol-chemistry-radiation-boundary layer interaction}

In order to further investigate the interaction between MLH and chemical compounds (either observed or calculated), we divided the observed $\mathrm{PM}_{2.5}$ concentrations into highly pol- luted and less polluted conditions using a threshold value of $75 \mu \mathrm{g} \mathrm{m}^{-3}$ for $\mathrm{PM}_{2.5}$. The organics, nitrate, ammonium, sulfate, chloride, HOM, aerosol water content (AWC) and $\mathrm{PM}_{2.5}$ as a function of the mixing layer height during both highly polluted and less polluted conditions are shown in Fig. 6. The fitted relationships connecting the concentrations of different chemical compounds to the reduction of MLH under highly and less polluted conditions allowed us to estimate the net mass concentration increase of each compound due to secondary formation and aerosol-chemical-boundary layer feedback under highly polluted conditions (shaded areas in Fig. 6). It is worth noting that AWC, nitrate and sulfate increased the most as the MLH decreased, as represented by the large shaded areas in Fig. 6h, b and c. The increases of these components are significant as tested (Supplement). The daytime nitrate in aerosol is formed predominately via the reaction of nitric acid and ammonium, while nitric acid is produced from gas-phase reaction of nitrogen dioxide and hydroxy radical (Seinfeld and Pandis, 2006). High concentrations of daytime nitrate aerosols indicate efficient production of gas-phase nitric acid, its partitioning into liquid aerosol and its fast neutralisation by abundant ammonia (H. Li et al., 2018; Pan et al., 2016; Y. Wang et al., 2020a). A recent study shows that condensation of nitric acid and ammonia could promote fast growth of newly formed particles in urban environment conditions (M. Wang et al., 2020). Another possibility is that ammonium nitrate is formed rapidly on par- 

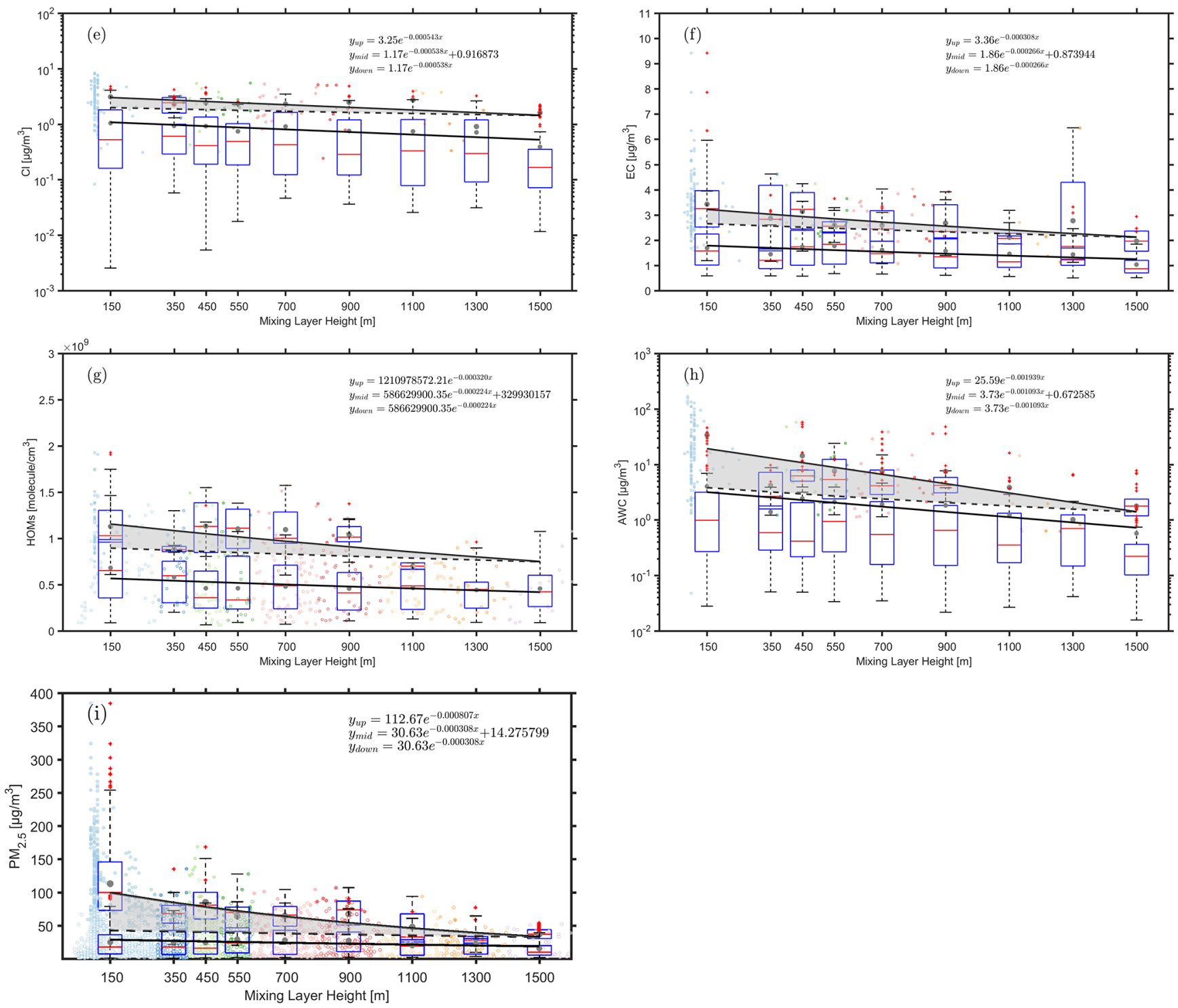

Figure 6. Observed dependency of organics (a), nitrate (b), ammonium (c), sulfate (d), chlorine (e), element carbon (f), HOMs (g), AWC (h) and $\mathrm{PM}_{2.5}(\mathrm{i})$ on the MLH during polluted and less-polluted conditions. The data related to the upper fitting line represent $\mathrm{PM}_{2.5}$ concentrations larger than $75 \mu \mathrm{g} \mathrm{m}^{-3}$, while the data related to the lower fitting line represent $\mathrm{PM}_{2.5}$ concentrations lower than $75 \mu \mathrm{g} \mathrm{m}^{-3}$. Only daytime conditions determined by the ceilometer from non-rainy periods $(\mathrm{RH}<95 \%)$ were considered. The solid cycles and hollow cycles denote concentrations that are more than $75 \mathrm{~g} \mathrm{~m}^{-3}$ and less than $75 \mu \mathrm{g} \mathrm{m}^{-3}$, respectively. The dark grey points and red lines in the boxes represent mean and median values, respectively. The shaded area between the upper solid and dotted lines corresponds to an increased amount of the specific compounds with decreased MLH, assuming that the compound has the same variation pattern under highly polluted conditions as in less polluted time.

ticle surfaces due to the hydrolysis of dinitrogen pentoxide $\left(\mathrm{N}_{2} \mathrm{O}_{5}\right)$ during daytime, as the AWC increased significantly (X. Wang et al., 2014; Y. Wang et al., 2020a). However, a quantitative distinction between the two formation pathways for nitrate formation is not possible in this study. The dramatic increase of nitrate aerosol could also promote the formation of sulfate by heterogeneous reactions (Cheng et al., 2016; Wang et al., 2016). The concentration of HOMs showed a slight increase as the MLH decreased, which sug- gests that also the formation of HOMs is enhanced with an increased level of air pollution. This phenomenon should be further investigated as HOMs can substantially contribute to the secondary organic aerosol formation.

Figure 7 displays the dry aerosol light extinction by different chemical compounds in the same way as Fig. 6 did for aerosol mass concentrations. The aerosol light extinction is directly related to the reduction of solar radiation reaching the surface, assuming that aerosol chemical components 

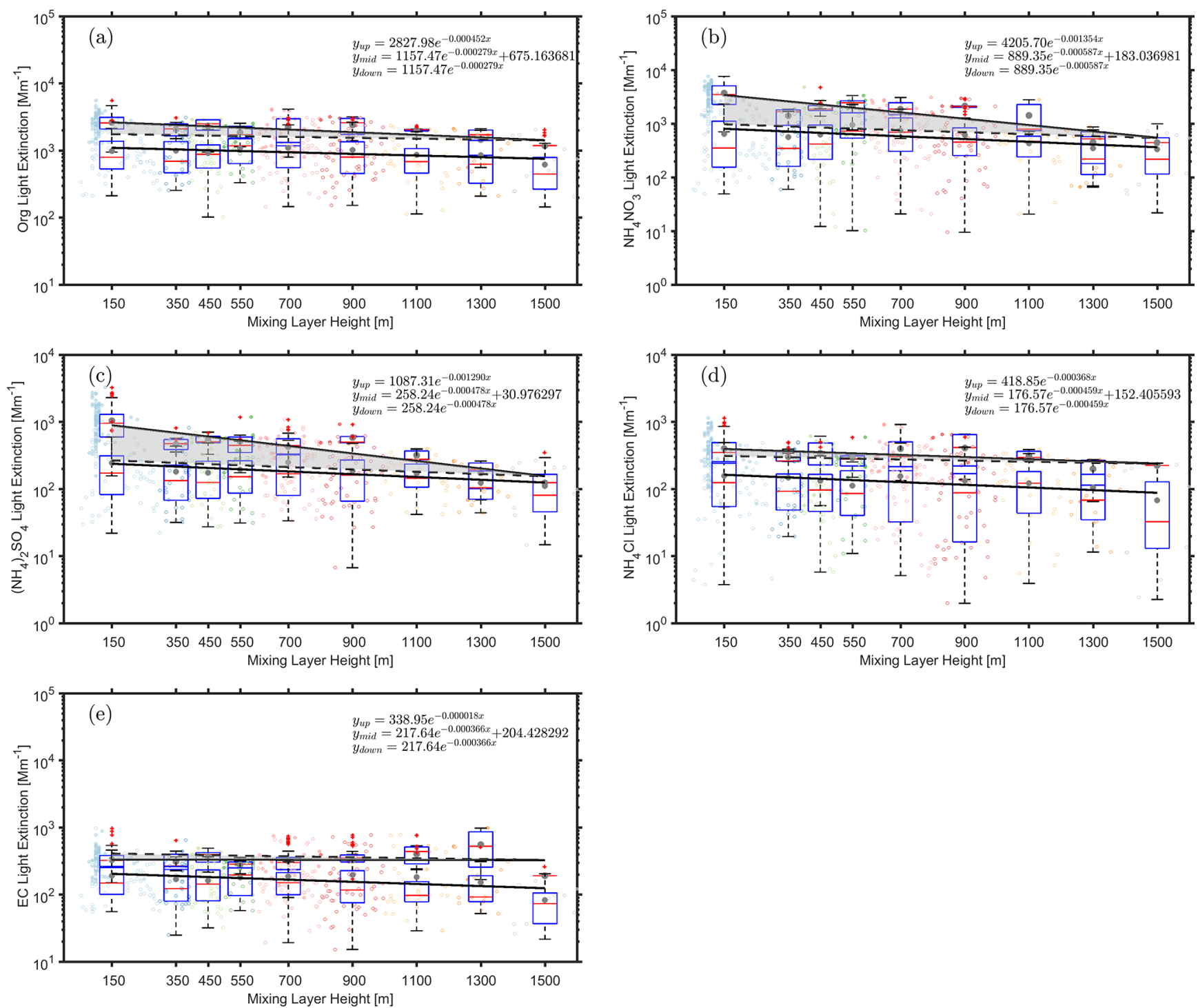

Figure 7. Observed dependency of the aerosol light extinction due to $\mathrm{NH}_{4} \mathrm{NO}_{3}(\mathbf{a}),\left(\mathrm{NH}_{4}\right)_{2} \mathrm{SO}_{4}(\mathbf{b}), \mathrm{NH}_{4} \mathrm{Cl}$ (c), Org (d), and EC (e) on the MLH during polluted and non-polluted conditions. The data related to the upper fitting line represent $\mathrm{PM}_{2.5}$ concentrations larger than $75 \mu \mathrm{g} \mathrm{m}^{-3}$, while the data related to the lower fitting line represent $\mathrm{PM}_{2.5}$ concentrations less than $75 \mu \mathrm{g} \mathrm{m}^{-3}$. Only daytime conditions determined by ceilometer from non-rainy periods $(\mathrm{RH}<95 \%)$ are considered. The dark grey points and red lines in the boxes represent mean and median values, respectively. The shaded area between the upper solid and dashed line corresponds to an increased amount of $\mathrm{PM}_{2.5}$ with a decreased $\mathrm{MLH}$, assuming that $\mathrm{PM}_{2.5}$ has the same variation pattern under highly polluted conditions as in less polluted time.

are vertically nearly homogeneously distributed. The light extinction from ammonium nitrate, ammonium sulfate and organics showed significantly increased contributions under highly polluted conditions (low MLH) as compared with less polluted conditions. To the contrary, no such enhancement was observed for ammonium chloride or element carbon (Fig. 7d and e). In the case of EC this is an expected result, as it originates solely from primary sources. The formation of particle-phase chloride has secondary sources from chlorine atom-initiated oxidation of volatile organic compounds so that the resulting oxidation products could contribute to the observed chloride (Y. Wang et al., 2020).

To better illustrate the combined effects of secondary aerosol formation and associated feedback on the daytime mass concentrations and light extinction due to different chemical components, we scaled these quantities by either the total $\mathrm{PM}_{2.5}$ mass concentration or EC concentration and plotted them as a function of MLH (Fig. 8). With the average level of $\mathrm{PM}_{2.5}$ measured by TEOM and ToF-ACSM, the latter scaling minimises the boundary layer accumulation effect on our analysis, as EC originates from primary emission 

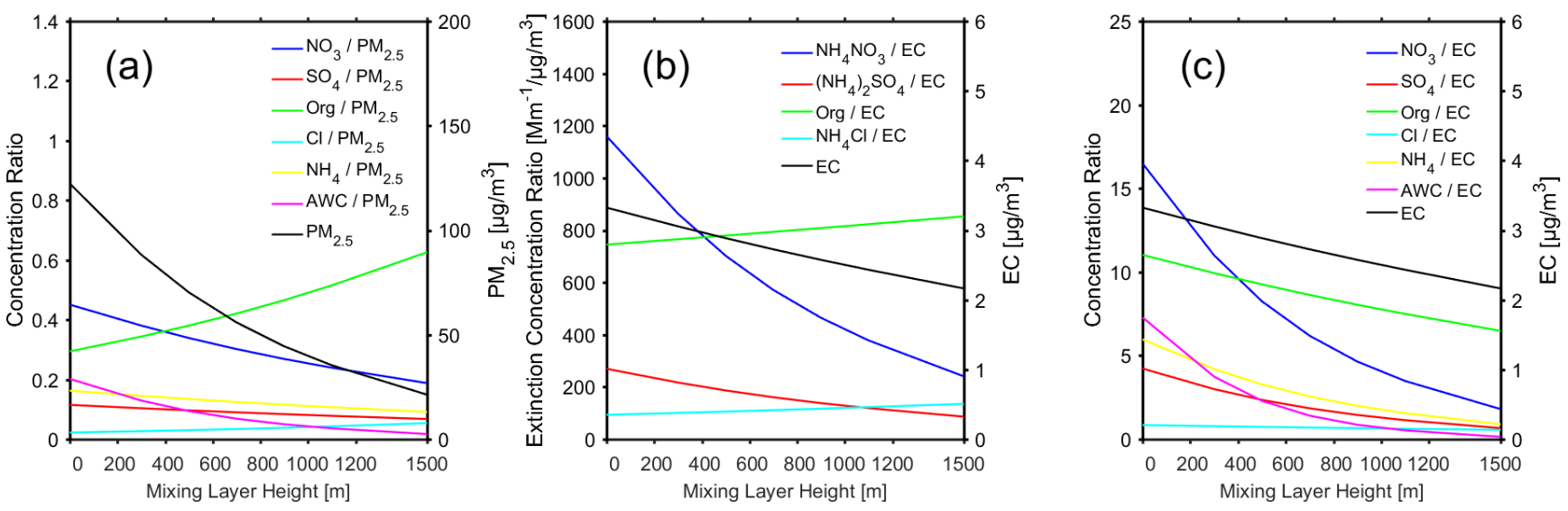

Figure 8. (a) The ratio of the mass concentration of different chemical components (nitrate, sulfate, organics, chlorine, ammonium) and AWC to the mass concentration of NR_PM 2.5 as a function of MLH. (b) The ratio of dry aerosol light extinction by different chemical components $\left(\mathrm{NH}_{4} \mathrm{NO}_{3},\left(\mathrm{NH}_{4}\right)_{2} \mathrm{SO}_{4}, \mathrm{Org}, \mathrm{NH}_{4} \mathrm{Cl}\right)$ to the mass concentration $\mathrm{EC}$ as a function of MLH. (c) The ratio of the mass concentration of different chemical components (nitrate, sulfate, organics, chlorine, ammonium) and AWC to the mass concentration of EC as a function of MLH. All the data correspond to polluted conditions (fine $\mathrm{PM}>75 \mu \mathrm{g} \mathrm{m}^{-3}$ ), and only daytime conditions determined by the ceilometer from non-rainy periods $(\mathrm{RH}<95 \%)$ were considered.

sources (Cao et al., 2006). As shown in Fig. 8a, organics with their mass fraction of $61 \%$ were the most abundant component in $\mathrm{PM}_{2.5}$ under high MLH conditions, followed by nitrate and ammonium with their mass fractions of $22 \%$ and $13 \%$, respectively. The aerosol was estimated to be rather dry under high $\mathrm{MLH}$ conditions $\left(\mathrm{AWC} / \mathrm{PM}_{2.5}=0.03\right)$. However, with the decreasing MLH, the fraction of nitrate and the AWC to $\mathrm{PM}_{2.5}$ ratio increased up to $45 \%$ and 0.2 , respectively. This clearly indicates rapid nitrate formation and dramatic increase of the aerosol water uptake from less polluted conditions to intensive haze pollution. Compared with EC (Fig. 8c), the concentrations of organic compounds, nitrate, sulfate and ammonium increased by factors of 1.5 , $6.3,4.8$ and 4.9 respectively, from the highest to the lowest MLH conditions. Thus, although organics remained as the second most abundant aerosol component after nitrate under haze conditions, secondary formation and associated feedback from less to highly polluted conditions were clearly stronger for both sulfate and ammonium. Efficient sulfate production associated with haze formation has been reported in several studies conducted in China (Cheng et al., 2016; Xie et al., 2015; Xue et al., 2016). Ammonium production during haze formation is tied with neutralisation of acidic aerosol by ammonia, which was apparently present abundantly in the gas phase. Compared with the EC concentration, light extinction by $\mathrm{NH}_{4} \mathrm{NO}_{3}$ increased the most from the highest MLH conditions $\left(248 \mathrm{Mm}^{-1} \mu \mathrm{g} \mathrm{m}^{-3}\right)$ to the lowest MLH conditions $\left(1150 \mathrm{Mm}^{-1} \mathrm{\mu g} \mathrm{m}^{-3}\right)$ as shown by Fig. 8b. Overall, the rapid growth of nitrate aerosol mass, together with abundant concentration of organic aerosol, was the main cause of the light extinction for dry aerosol under haze formation.

The mechanism governing the aerosol-chemistryradiation-boundary layer feedback for the rapid growth of atmospheric aerosol is illustrated in Fig. 9. As a result of reduction in solar radiation and atmospheric heating, a variety of chemical reactions in the gas phase and on particle surfaces or inside them are enhanced with an increased relative humidity and AWC. Such conditions are unfavourable for the dispersion of pollutants, which further enhances atmospheric stability. The formation of hydrophilic compounds, e.g. nitrate, sulfate and oxygenated organic compounds, results in enhanced water uptake by aerosol particles, which will essentially increase heterogeneous reactions associated with these particles. As a result, the aerosol mass and size increase, light extinction is enhanced, and the development of the mixing layer is depressed. At the same time, aerosol precursors concentrated within a shallower mixing layer lead to enhanced production rate of aerosol components in both gas and aerosol phases, especially nitrate but also other secondary aerosol. The increased concentrations of aerosol will further enhance this positive loop.

\section{Conclusions}

We investigated the synergetic variations of aerosol chemical composition and mixing layer height during the daytime in urban Beijing. Significant dependency of the sharp increase of ammonium nitrate and aerosol water content with the occurrence of the explosive aerosol mass growth events were observed. We showed that these two components drove a positive aerosol-chemistry-radiation-boundary layer feedback loop, which played an important role in the explosive aerosol mass growth events. A plausible explanation is that the increased aerosol water content at low mixing layer heights provides favourable conditions for heteroge- 


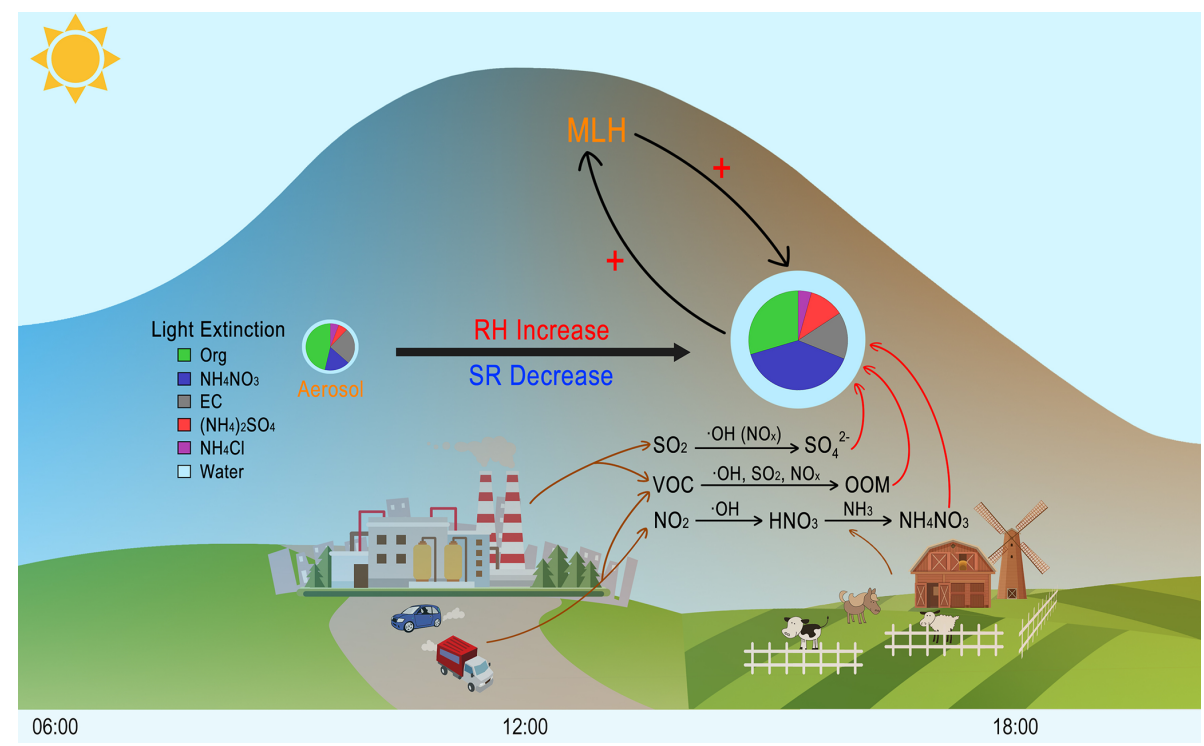

Figure 9. A schematic picture illustrating the process of rapid aerosol mass growth and enhanced light extinction in Beijing. The plus symbols represent the strengthening of a specific process. At the presence of aerosols during afternoon time in Beijing, the intensity of solar radiation reaching the surface will be decreased and relative humidity will be increased. As a result, the development of boundary layer will be suppressed, and the concentrations of aerosol precursors (e.g. $\mathrm{SO}_{2}, \mathrm{NO}_{2}$, VOC) will be increased. In turn, the secondary production of these sulfate, nitrate and oxygenated organic compounds will be enhanced due to increased concentrations and partitioning of these compounds into the aerosol phase. The increased formation of secondary aerosol mass will reduce solar radiation further and the haze formation increased, as shown in pie charts that the light extinction fraction of aerosol changed from organic to nitrate. Noting that during intensive haze periods, nitrate and its contribution to light extinction contribution increased dramatically.

neous reactions for nitrate and sulfate production and neutralisation by ammonia. The significant formation of secondary aerosol increases the concentration of aerosol particles in the diameter range $300-700 \mathrm{~nm}$, which effectively reduces the solar radiation reaching the surface and further enhances the aerosol-chemistry-radiation-boundary layer feedback loop. Our analysis connects the aerosol light extinction to a reduction in the mixing layer height, which suppresses the volume into which air pollutants are emitted and leads to an explosive aerosol mass growth. Our results indicate that reduction of ammonium and nitrate concentration in aerosol could weaken the aerosol-radiation-chemistryboundary layer feedback loop, which could thereby reduce heavy haze episodes in Beijing.

Code availability. The code can be accessed via contacting Yonghong Wang (yonghongwang@rcees.ac.cn).

Data availability. The data presented in the paper can be accessed via contacting Yonghong Wang (yonghongwang@rcees.ac.cn).

Supplement. The supplement related to this article is available online at: https://doi.org/10.5194/acp-21-12173-2021-supplement.
Author contributions. YW and MK initiated the study. ZL, YW, FZ, YZ, YG, ZF, CL, YZ, TC, CY, KD, BC, JK, LY, XF, WD, JC and YL conducted the long-term measurements. ZL, YW, LD, RC, SH, PZ, LW, VK, YL and MK interpreted the data. ZL, YW and VK wrote the manuscript.

Competing interests. The authors declare that they have no conflict of interest.

Disclaimer. Publisher's note: Copernicus Publications remains neutral with regard to jurisdictional claims in published maps and institutional affiliations.

Acknowledgements. This work was supported by funding from Beijing University of Chemical Technology, the European Research Council via advanced grant ATM-GTP (project no. 742206) and the Academy of Finland via an academy professor project of Markku Kulmala.

Financial support. This research has been supported by the European Research Council (grant no. 742206) and the BUCT project. 
Open-access funding was provided by the Helsinki University Library.

Review statement. This paper was edited by Laurens Ganzeveld and reviewed by three anonymous referees.

\section{References}

Aalto, P., Hämeri, K., Becker, E. D. O., Weber, R., Salm, J., Mäkelä, J. M., Hoell, C., O’Dowd, C. D., Karlsson, H., Hansson, H., Väkevä, M., Koponen, I. K., Buzorius, G., and Kulmala, M.: Physical characterization of aerosol particles during nucleation events, Tellus B, 53, 344-358, https://doi.org/10.3402/tellusb.v53i4.17127, 2001.

An, Z., Huang, R.-J., Zhang, R., Tie, X., Li, G., Cao, J., Zhou, W., Shi, Z., Han, Y., Gu, Z., and Ji, Y.: Severe haze in northern China: A synergy of anthropogenic emissions and atmospheric processes, P. Natl. Acad. Sci. USA, 116, 8657-8666, https://doi.org/10.1073/pnas.1900125116, 2019.

Baxter, R.: Determination of mixing heights from data collected during the 1985 SCCCAMP field program, J. Appl. Meteorol., 30, 598-606, https://doi.org/10.1175/15200450(1991)030<0598:DOMHFD>2.0.CO;2, 1991.

Cai, J., Chu, B., Yao, L., Yan, C., Heikkinen, L. M., Zheng, F., Li, C., Fan, X., Zhang, S., Yang, D., Wang, Y., Kokkonen, T. V., Chan, T., Zhou, Y., Dada, L., Liu, Y., He, H., Paasonen, P., Kujansuu, J. T., Petäjä, T., Mohr, C., Kangasluoma, J., Bianchi, F., Sun, Y., Croteau, P. L., Worsnop, D. R., Kerminen, V.-M., Du, W., Kulmala, M., and Daellenbach, K. R.: Size-segregated particle number and mass concentrations from different emission sources in urban Beijing, Atmos. Chem. Phys., 20, 1272112740, https://doi.org/10.5194/acp-20-12721-2020, 2020.

Cao, G., Zhang, X., and Zheng, F.: Inventory of black carbon and organic carbon emissions from China, Atmos. Environ., 40, 65166527, https://doi.org/10.1016/j.atmosenv.2006.05.070, 2006.

Che, H., Zhang, X., Li, Y., Zhou, Z., and Qu, J. J.: Horizontal visibility trends in China 1981-2005, Geophys. Res. Lett., 34, L24706, https://doi.org/10.1029/2007GL031450, 2007.

Chen, J., Zhao, C. S., Ma, N., and Yan, P.: Aerosol hygroscopicity parameter derived from the light scattering enhancement factor measurements in the North China Plain, Atmos. Chem. Phys., 14, 8105-8118, https://doi.org/10.5194/acp-14-8105-2014, 2014.

Cheng, Y., Zheng, G., Wei, C., Mu, Q., Zheng, B., Wang, Z., Gao, M., Zhang, Q., He, K., Carmichael, G., Pöschl, U., and $\mathrm{Su}, \mathrm{H} .:$ Reactive nitrogen chemistry in aerosol water as a source of sulfate during haze events in China, Science Advances, 2, e1601530-e1601530, https://doi.org/10.1126/sciadv.1601530, 2016.

Ding, A. J., Huang, X., Nie, W., Sun, J. N., Kerminen, V. M., Petäjä, T., Su, H., Cheng, Y. F., Yang, X. Q., Wang, M. H., Chi, X. G., Wang, J. P., Virkkula, A., Guo, W. D., Yuan, J., Wang, S. Y., Zhang, R. J., Wu, Y. F., Song, Y., Zhu, T., Zilitinkevich, S., Kulmala, M., and Fu, C. B.: Enhanced haze pollution by black carbon in megacities in China, Geophys. Res. Lett., 43, 2873-2879, https://doi.org/10.1002/2016GL067745, 2016.

Eresmaa, N., Härkönen, J., Joffre, S. M., Schultz, D. M., Karppinen, A., and Kukkonen, J.: A Three-Step Method for Es- timating the Mixing Height Using Ceilometer Data from the Helsinki Testbed, J. Appl. Meteorol. Clim., 51, 2172-2187, https://doi.org/10.1175/JAMC-D-12-058.1, 2012.

Fountoukis, C. and Nenes, A.: ISORROPIA II: a computationally efficient thermodynamic equilibrium model for $\mathrm{K}^{+}-\mathrm{Ca}^{2+}-\mathrm{Mg}^{2+}-\mathrm{NH}_{4}^{+}-\mathrm{Na}^{+}-\mathrm{SO}_{4}^{2-}-\mathrm{NO}_{3}^{-}-\mathrm{Cl}^{-}-\mathrm{H}_{2} \mathrm{O}$ aerosols, Atmos. Chem. Phys., 7, 4639-4659, https://doi.org/10.5194/acp-7-4639-2007, 2007.

Fröhlich, R., Cubison, M. J., Slowik, J. G., Bukowiecki, N., Prévôt, A. S. H., Baltensperger, U., Schneider, J., Kimmel, J. R., Gonin, M., Rohner, U., Worsnop, D. R., and Jayne, J. T.: The ToF-ACSM: a portable aerosol chemical speciation monitor with TOFMS detection, Atmos. Meas. Tech., 6, 3225-3241, https://doi.org/10.5194/amt-6-3225-2013, 2013.

Gysel, M., Crosier, J., Topping, D. O., Whitehead, J. D., Bower, K. N., Cubison, M. J., Williams, P. I., Flynn, M. J., McFiggans, G. B., and Coe, H.: Closure study between chemical composition and hygroscopic growth of aerosol particles during TORCH2, Atmos. Chem. Phys., 7, 6131-6144, https://doi.org/10.5194/acp-7-6131-2007, 2007.

Holzworth, G. C.: Mixing heights, wind speeds, and potential for urban air pollution throughout the contiguous united states, Environmental Protection Agency, Office of Air Programs Researc, Triangle Park, North Carolina, 3 pp., 1972.

Jimenez, J. L., Canagaratna, M. R., Donahue, N. M., Prevot, A. S. H., Zhang, Q., Kroll, J. H., DeCarlo, P. F., Allan, J. D., Coe, H., Ng, N. L., Aiken, A. C., Docherty, K. S., Ulbrich, I. M., Grieshop, A. P., Robinson, A. L., Duplissy, J., Smith, J. D., Wilson, K. R., Lanz, V. A., Hueglin, C., Sun, Y. L., Tian, J., Laaksonen, A., Raatikainen, T., Rautiainen, J., Vaattovaara, P., Ehn, M., Kulmala, M., Tomlinson, J. M., Collins, D. R., Cubison, M. J., Dunlea, E. J., Huffman, J. A., Onasch, T. B., Alfarra, M. R., Williams, P. I., Bower, K., Kondo, Y., Schneider, J., Drewnick, F., Borrmann, S., Weimer, S., Demerjian, K., Salcedo, D., Cottrell, L., Griffin, R., Takami, A., Miyoshi, T., Hatakeyama, S., Shimono, A., Sun, J. Y., Zhang, Y. M., Dzepina, K., Kimmel, J. R., Sueper, D., Jayne, J. T., Herndon, S. C., Trimborn, A. M., Williams, L. R., Wood, E. C., Middlebrook, A. M., Kolb, C. E., Baltensperger, U., and Worsnop, D. R.: Evolution of organic aerosols in the atmosphere, Science, 326, 1525-1529, https://doi.org/10.1126/science.1180353, 2009.

Jokinen, T., Sipilä, M., Junninen, H., Ehn, M., Lönn, G., Hakala, J., Petäjä, T., Mauldin III, R. L., Kulmala, M., and Worsnop, D. R.: Atmospheric sulphuric acid and neutral cluster measurements using CI-APi-TOF, Atmos. Chem. Phys., 12, 4117-4125, https://doi.org/10.5194/acp-12-4117-2012, 2012.

Lelieveld, J., Evans, J. S., Fnais, M., Giannadaki, D., and Pozzer, A.: The contribution of outdoor air pollution sources to premature mortality on a global scale, Nature, 525, 367-371, https://doi.org/10.1038/nature15371, 2015.

Li, H., Zhang, Q., Zheng, B., Chen, C., Wu, N., Guo, H., Zhang, Y., Zheng, Y., Li, X., and He, K.: Nitrate-driven urban haze pollution during summertime over the North China Plain, Atmos. Chem. Phys., 18, 5293-5306, https://doi.org/10.5194/acp-185293-2018, 2018.

Li, J., Sun, J., Zhou, M., Cheng, Z., Li, Q., Cao, X., and Zhang, J.: Observational analyses of dramatic developments of a severe air pollution event in the Beijing area, Atmos. Chem. Phys., 18, 3919-3935, https://doi.org/10.5194/acp-18-3919-2018, 2018. 
Lin, Z. J., Tao, J., Chai, F. H., Fan, S. J., Yue, J. H., Zhu, L. H., Ho, K. F., and Zhang, R. J.: Impact of relative humidity and particles number size distribution on aerosol light extinction in the urban area of Guangzhou, Atmos. Chem. Phys., 13, 1115-1128, https://doi.org/10.5194/acp-13-1115-2013, 2013.

Liu, G., Xin, J., Wang, X., Si, R., Ma, Y., Wen, T., Zhao, L., Zhao, D., Wang, Y., and Gao, W.: Impact of the coal banning zone on visibility in the BeijingTianjin-Hebei region, Sci. Total Environ., 692, 402-410, https://doi.org/10.1016/j.scitotenv.2019.07.006, 2019.

Liu, Q., Jia, X., Quan, J., Li, J., Li, X., Wu, Y., Chen, D., Wang, Z., and Liu, Y.: New positive feedback mechanism between boundary layer meteorology and secondary aerosol formation during severe haze events, Sci. Rep.-UK, 8, 6095, https://doi.org/10.1038/s41598-018-24366-3, 2018.

Liu, Y., Zhang, Y., Lian, C., Yan, C., Feng, Z., Zheng, F., Fan, X., Chen, Y., Wang, W., Chu, B., Wang, Y., Cai, J., Du, W., Daellenbach, K. R., Kangasluoma, J., Bianchi, F., Kujansuu, J., Petäjä, T., Wang, X., Hu, B., Wang, Y., Ge, M., He, H., and Kulmala, M.: The promotion effect of nitrous acid on aerosol formation in wintertime in Beijing: the possible contribution of traffic-related emissions, Atmos. Chem. Phys., 20, 13023-13040, https://doi.org/10.5194/acp-20-13023-2020, 2020.

Liu, Z., Hu, B., Ji, D., Cheng, M., Gao, W., Shi, S., Xie, Y., Yang, S., Gao, M., Fu, H., Chen, J., and Wang, Y.: Characteristics of fine particle explosive growth events in Beijing, China: Seasonal variation, chemical evolution pattern and formation mechanism, Sci. Total Environ., 687, 1073-1086, https://doi.org/10.1016/j.scitotenv.2019.06.068, 2019.

Münkel, C., Eresmaa, N., Räsänen, J., and Karppinen, A.: Retrieval of mixing height and dust concentration with lidar ceilometer, Bound.-Lay. Meteorol., 124, 117-128, https://doi.org/10.1007/s10546-006-9103-3, 2007.

Pan, X. L., Yan, P., Tang, J., Ma, J. Z., Wang, Z. F., Gbaguidi, A., and Sun, Y. L.: Observational study of influence of aerosol hygroscopic growth on scattering coefficient over rural area near Beijing mega-city, Atmos. Chem. Phys., 9, 7519-7530, https://doi.org/10.5194/acp-9-7519-2009, 2009.

Pan, Y., Tian, S., Liu, D., Fang, Y., Zhu, X., Zhang, Q., Zheng, B., Michalski, G., and Wang, Y.: Fossil Fuel Combustion-Related Emissions Dominate Atmospheric Ammonia Sources during Severe Haze Episodes: Evidence from 15N-Stable Isotope in SizeResolved Aerosol Ammonium, Environ. Sci. Technol., 50, 80498056, https://doi.org/10.1021/acs.est.6b00634, 2016.

Petäjä, T., Järvi, L., Kerminen, V. M., Ding, A. J., Sun, J. N., Nie, W., Kujansuu, J., Virkkula, A., Yang, X., Fu, C. B., Zilitinkevich, S., and Kulmala, M.: Enhanced air pollution via aerosolboundary layer feedback in China, Sci. Rep.-UK, 6, 18998, https://doi.org/10.1038/srep18998, 2016.

Pieber, S. M., El Haddad, I., Slowik, J. G., Canagaratna, M. R., Jayne, J. T., Platt, S. M., Bozzetti, C., Daellenbach, K. R., Fröhlich, R., Vlachou, A., Klein, F., Dommen, J., Miljevic, B., Jiménez, J. L., Worsnop, D. R., Baltensperger, U., and Prévôt, A. S. H.: Inorganic Salt Interference on $\mathrm{CO}_{2}^{+}$ in Aerodyne AMS and ACSM Organic Aerosol Composition Studies, Environ. Sci. Technol., 50, 10494-10503, https://doi.org/10.1021/acs.est.6b01035, 2016.

Seinfeld, J. H. and Pandis, S. N.: Atmospheric chemistry and physics: from air pollution to climate change, 3rd Edn., John
Wiley \& Sons, Inc., Hoboken, New Jersey, USA, ISBN 978-1118-94740-1, 2016.

Spracklen, D. V., Carslaw, K. S., Kulmala, M., Kerminen, V. M., Sihto, S. L., Riipinen, I., Merikanto, J., Mann, G. W., Chipperfield, M. P., Wiedensohler, A., Birmili, W., and Lihavainen, H.: Contribution of particle formation to global cloud condensation nuclei concentrations, Geophys. Res. Lett., 35, L06808, https://doi.org/10.1029/2007GL033038, 2008.

Stohl, A., Forster, C., Frank, A., Seibert, P., and Wotawa, G.: Technical note: The Lagrangian particle dispersion model FLEXPART version 6.2, Atmos. Chem. Phys., 5, 2461-2474, https://doi.org/10.5194/acp-5-2461-2005, 2005.

Swietlicki, E., Hansson, H.-C., Hämeri, K., Svenningsson, B., Massling, A., Mcfiggans, G., Mcmurry, P. H., Petäjä, T., Tunved, P., Gysel, M., Topping, D., Weingartner, E., Baltensperger, U., Rissler, J., Wiedensohler, A., and Kulmala, M.: Hygroscopic properties of submicrometer atmospheric aerosol particles measured with H-TDMA instruments in various environments - a review, Tellus B, 60, 432-469, https://doi.org/10.1111/j.1600-0889.2008.00350.x, 2008.

Tang, G., Zhang, J., Zhu, X., Song, T., Münkel, C., Hu, B., Schäfer, K., Liu, Z., Zhang, J., Wang, L., Xin, J., Suppan, P., and Wang, Y.: Mixing layer height and its implications for air pollution over Beijing, China, Atmos. Chem. Phys., 16, 2459-2475, https://doi.org/10.5194/acp-16-2459-2016, 2016.

Titos, G., Cazorla, A., Zieger, P., Andrews, E., Lyamani, H., Granados-Muñoz, M. J., Olmo, F. J., and AladosArboledas, L.: Effect of hygroscopic growth on the aerosol light-scattering coefficient: A review of measurements, techniques and error sources, Atmos. Environ., 141, 494-507, https://doi.org/10.1016/j.atmosenv.2016.07.021, 2016.

Wang, G., Zhang, R., Gomez, M. E., Yang, L., Zamora, M. L., Hu, M., Lin, Y., Peng, J., Guo, S., Meng, J., Li, J., Cheng, C., Hu, T., Ren, Y., Wang, Y., Gao, J., Cao, J., An, Z., Zhou, W., Li, G., Wang, J., Tian, P., Marrero-Ortiz, W., Secrest, J., Du, Z., Zheng, J., Shang, D., Zeng, L., Shao, M., Wang, W., Huang, Y., Wang, Y., Zhu, Y., Li, Y., Hu, J., Pan, B., Cai, L., Cheng, Y., Ji, Y., Zhang, F., Rosenfeld, D., Liss, P. S., Duce, R. A., Kolb, C. E., and Molina, M. J.: Persistent sulfate formation from London Fog to Chinese haze, P. Natl. Acad. Sci. USA, 113, 13630-13635, https://doi.org/10.1073/pnas.1616540113, 2016.

Wang, H., Peng, Y., Zhang, X., Liu, H., Zhang, M., Che, H., Cheng, Y., and Zheng, Y.: Contributions to the explosive growth of $\mathrm{PM}_{2.5}$ mass due to aerosol-radiation feedback and decrease in turbulent diffusion during a red alert heavy haze in BeijingTianjin-Hebei, China, Atmos. Chem. Phys., 18, 17717-17733, https://doi.org/10.5194/acp-18-17717-2018, 2018.

Wang, J., Wang, S., Jiang, J., Ding, A., Zheng, M., Zhao, B., Wong, D. C., Zhou, W., Zheng, G., Wang, L., Pleim, J. E., and Hao, J.: Impact of aerosol-meteorology interactions on fine particle pollution during China's severe haze episode in January 2013, Environ. Res. Lett., 9, 094002, https://doi.org/10.1088/17489326/9/9/094002, 2014.

Wang, M., Kong, W., Marten, R., He, X.-C., Chen, D., Pfeifer, J., Heitto, A., Kontkanen, J., Dada, L., Kürten, A., Yli-Juuti, T., Manninen, H. E., Amanatidis, S., Amorim, A., Baalbaki, R., Baccarini, A., Bell, D. M., Bertozzi, B., Bräkling, S., Brilke, S., Murillo, L. C., Chiu, R., Chu, B., De Menezes, L.-P., Duplissy, J., Finkenzeller, H., Carracedo, L. G., Granzin, M., 
Guida, R., Hansel, A., Hofbauer, V., Krechmer, J., Lehtipalo, K., Lamkaddam, H., Lampimäki, M., Lee, C. P., Makhmutov, V., Marie, G., Mathot, S., Mauldin, R. L., Mentler, B., Müller, T., Onnela, A., Partoll, E., Petäjä, T., Philippov, M., Pospisilova, V., Ranjithkumar, A., Rissanen, M., Rörup, B., Scholz, W., Shen, J., Simon, M., Sipilä, M., Steiner, G., Stolzenburg, D., Tham, Y. J., Tomé, A., Wagner, A. C., Wang, D. S., Wang, Y., Weber, S. K., Winkler, P. M., Wlasits, P. J., Wu, Y., Xiao, M., Ye, Q., Zauner-Wieczorek, M., Zhou, X., Volkamer, R., Riipinen, I., Dommen, J., Curtius, J., Baltensperger, U., Kulmala, M., Worsnop, D. R., Kirkby, J., Seinfeld, J. H., ElHaddad, I., Flagan, R. C., and Donahue, N. M.: Rapid growth of new atmospheric particles by nitric acid and ammonia condensation, Nature, 581, 184-189, https://doi.org/10.1038/s41586-0202270-4, 2020.

Wang, X., Wang, T., Yan, C., Tham, Y. J., Xue, L., Xu, Z., and $\mathrm{Zha}, \mathrm{Q}$.: Large daytime signals of $\mathrm{N}_{2} \mathrm{O}_{5}$ and $\mathrm{NO}_{3}$ inferred at $62 \mathrm{amu}$ in a TD-CIMS: chemical interference or a real atmospheric phenomenon?, Atmos. Meas. Tech., 7, 1-12, https://doi.org/10.5194/amt-7-1-2014, 2014.

Wang, Y., Wang, Y., Wang, L., Petäjä, T., Zha, Q., Gong, C., Li, S., Pan, Y., Hu, B., Xin, J., and Kulmala, M.: Increased inorganic aerosol fraction contributes to air pollution and haze in China, Atmos. Chem. Phys., 19, 5881-5888, https://doi.org/10.5194/acp-19-5881-2019, 2019.

Wang, Y., Riva, M., Xie, H., Heikkinen, L., Schallhart, S., Zha, Q., Yan, C., He, X.-C., Peräkylä, O., and Ehn, M.: Formation of highly oxygenated organic molecules from chlorine-atominitiated oxidation of alpha-pinene, Atmos. Chem. Phys., 20, 5145-5155, https://doi.org/10.5194/acp-20-5145-2020, 2020a.

Wang, Y., Gao, W., Wang, S., Song, T., Gong, Z., Ji, D., Wang, L., Liu, Z., Tang, G., Huo, Y., Tian, S., Li, J., Li, M., Yang, Y., Chu, B., Petäjä, T., Kerminen, V.-M., He, H., Hao, J., Kulmala, M., Wang, Y., and Zhang, Y.: Contrasting trends of $\mathrm{PM}_{2.5}$ and surface ozone concentrations in China from 2013 to 2017, Natl. Sci. Rev., 7, 1331-1339, https://doi.org/10.1093/nsr/nwaa032, 2020b.

Wang, Y., Chen, Y., Wu, Z., Shang, D., Bian, Y., Du, Z., Schmitt, S. H., Su, R., Gkatzelis, G. I., Schlag, P., Hohaus, T., Voliotis, A., Lu, K., Zeng, L., Zhao, C., Alfarra, M. R., McFiggans, G., Wiedensohler, A., Kiendler-Scharr, A., Zhang, Y., and $\mathrm{Hu}$, M.: Mutual promotion between aerosol particle liquid water and particulate nitrate enhancement leads to severe nitratedominated particulate matter pollution and low visibility, Atmos. Chem. Phys., 20, 2161-2175, https://doi.org/10.5194/acp20-2161-2020, 2020c.

Wang, Y., Yu, M., Wang, Y., Tang, G., Song, T., Zhou, P., Liu, Z., Hu, B., Ji, D., Wang, L., Zhu, X., Yan, C., Ehn, M., Gao, W., Pan, Y., Xin, J., Sun, Y., Kerminen, V.-M., Kulmala, M., and Petäjä, T.: Rapid formation of intense haze episodes via aerosolboundary layer feedback in Beijing, Atmos. Chem. Phys., 20, 45-53, https://doi.org/10.5194/acp-20-45-2020, 2020d.
Wang, Y. H., Hu, B., Ji, D. S., Liu, Z. R., Tang, G. Q., Xin, J. Y., Zhang, H. X., Song, T., Wang, L. L., Gao, W. K., Wang, X. K., and Wang, Y. S.: Ozone weekend effects in the Beijing-TianjinHebei metropolitan area, China, Atmos. Chem. Phys., 14, 2419 2429, https://doi.org/10.5194/acp-14-2419-2014, 2014.

Wang, Y. H., Liu, Z. R., Zhang, J. K., Hu, B., Ji, D. S., Yu, Y. C., and Wang, Y. S.: Aerosol physicochemical properties and implications for visibility during an intense haze episode during winter in Beijing, Atmos. Chem. Phys., 15, 3205-3215, https://doi.org/10.5194/acp-15-3205-2015, 2015.

Wu, Z., Wang, Y., Tan, T., Zhu, Y., Li, M., Shang, D., Wang, H., Lu, K., Guo, S., Zeng, L., and Zhang, Y.: Aerosol Liquid Water Driven by Anthropogenic Inorganic Salts: Implying Its Key Role in Haze Formation over the North China Plain, Environ. Sci. Tech. Let., 5, 160-166, https://doi.org/10.1021/acs.estlett.8b00021, 2018.

Xie, Y., Ding, A., Nie, W., Mao, H., Qi, X., Huang, X., Xu, Z., Kerminen, V. M., Petäjä, T., Chi, X., Virkkula, A., Boy, M., Xue, L., Guo, J., Sun, J., Yang, X., Kulmala, M., and Fu, C.: Enhanced sulfate formation by nitrogen dioxide: Implications from insitu observations at the SORPES station, J. Geophys. Res., 120, 12679-12694, https://doi.org/10.1002/2015JD023607, 2015.

Xue, J., Yuan, Z., Griffith, S. M., Yu, X., Lau, A. K. H., and Yu, J. Z.: Sulfate Formation Enhanced by a Cocktail of High $\mathrm{NO}_{x}, \mathrm{SO}_{2}$, Particulate Matter, and Droplet $\mathrm{pH}$ during HazeFog Events in Megacities in China: An Observation-Based Modeling Investigation, Environ. Sci. Technol., 50, 7325-7334, https://doi.org/10.1021/acs.est.6b00768, 2016.

Xue, J., Yu, X., Yuan, Z., Griffith, S. M., Lau, A. K. H., Seinfeld, J. H., and Yu, J. Z.: Efficient control of atmospheric sulfate production based on three formation regimes, Nat. Geosci., 12, 1-6, https://doi.org/10.1038/s41561-019-0485-5, 2019.

Zheng, B., Tong, D., Li, M., Liu, F., Hong, C., Geng, G., Li, H., Li, X., Peng, L., Qi, J., Yan, L., Zhang, Y., Zhao, H., Zheng, Y., He, K., and Zhang, Q.: Trends in China's anthropogenic emissions since 2010 as the consequence of clean air actions, Atmos. Chem. Phys., 18, 14095-14111, https://doi.org/10.5194/acp-1814095-2018, 2018.

Zhong, J., Zhang, X., Dong, Y., Wang, Y., Liu, C., Wang, J., Zhang, Y., and Che, H.: Feedback effects of boundarylayer meteorological factors on cumulative explosive growth of $\mathrm{PM}_{2.5}$ during winter heavy pollution episodes in Beijing from 2013 to 2016, Atmos. Chem. Phys., 18, 247-258, https://doi.org/10.5194/acp-18-247-2018, 2018.

Zhou, Y., Dada, L., Liu, Y., Fu, Y., Kangasluoma, J., Chan, T., Yan, C., Chu, B., Daellenbach, K. R., Bianchi, F., Kokkonen, T. V., Liu, Y., Kujansuu, J., Kerminen, V.-M., Petäjä, T., Wang, L., Jiang, J., and Kulmala, M.: Variation of size-segregated particle number concentrations in wintertime Beijing, Atmos. Chem. Phys., 20, 1201-1216, https://doi.org/10.5194/acp-201201-2020, 2020. 